\title{
Internalisasi Tasawuf Al-Ghazali pada Masa Pandemi Covid-19
}

\author{
M Khusnun Niam, ${ }^{\mathbf{1}}$ Rahmad Tri Hadi ${ }^{2}$ \\ ${ }^{1}$ Universitas Islam Sunan Kalijaga Yogyakarta, Indonesia \\ ${ }^{2}$ Universitas Islam Sunan Kalijaga Yogyakarta, Indonesia \\ ${ }^{I}$ nunsorbansastra@gmail.com, ${ }^{2}$ rahmadtrihadi@gmail.com
}

\begin{abstract}
This article aims to describe, explain and analyze current topics, including those related to the covid-19 outbreak. Departing from the moral problems of humanity that are created from human responses to the current adult co-19 outbreak, thus forming panic and fear. The humanitarian crisis has become a fact that really happens in the field, many poor people are starving, criminality, and of course related co-19 namely the rejection of the body is also its relationship with the critical reasoning of a human and servant's religiosity. This research is a qualitative literature study, with a descriptiveanalysis approach, which is an approach used to describe the data obtained and then analyzed and presented in the form of a description. In addition, the approach in this study uses the concept of the 'makrifat' and Sufism Ghazali. The results of this study show that as a human being who is in this global pandemic, he should repent and forsake all sinful deeds. The existence of the corona virus teaches humans to rethink worldly matters. For this reason, it is fitting for humans to know their God so that they can always be grateful and remember their God.
\end{abstract}

\section{Keywords: Al-Ghazali, Covid-19, Makrifat, Sufism}

\begin{abstract}
Abstrak
Artikel ini bertujuan mendeskripsikan, menjelaskan dan menganalisis topik terkini, di antaranya yakni terkait wabah covid-19. Berangkat dari persoalan moral kemanusiaan yang tercipta dari respon manusia atas wabah covid-19 dewasa kini, sehingga membentuk kepanikan dan ketakutan. Krisis kemanusiaan telah menjadi fakta yang benar-benar terjadi dilapangan, banyak berbagai kaum miskin yang kelaparan, kriminalitas, dan tentunya terkait covid-19 yakni penolakan jenazah juga hubungannya dengan nalar kritis keberagamaan seorang manusia dan hamba. Penelitian ini merupakan penelitian kualitatif pustaka, dengan pendekatan deskriptif-analisis, yakni pendekatan yang digunakan untuk mendeksripsikan data-data yang didapat kemudian dianalisis dan disajikan dalam bentuk deskripsi. Selain itu, pendekatan dalam penelitian ini menggunakan konsep makrifat dan tasawuf Al-Ghazali. Hasil dari penelitian ini menunjukkan bahwa selaku seorang manusia yang sedang berada dalam pandemik global ini, sudah seharusnya bertaubat dan meninggalkan segala perbuatan keji yang berdosa. Eksistensi virus corona mengajarkan manusia harus memikirkan kembali tentang perihal keduniawian. Untuk itu, maka sudah sepatutnya manusa mengenal Tuhannya sehingga mereka dapat selalu dalam keadaan bersyukur dan mengingat Tuhannya.
\end{abstract}

Kata Kunci: Al-Ghazali, Covid-19, Makrifat, Tasawuf

\section{Pendahuluan}

Kehidupan mistik di era milenial kini semakin menggejala di beberapa kalangan masyarakat, terkhusus yang memahami juga mendalami dunia sufistik. Trend mistik dan 
sufistik di kehidupan sekarang bukan saja merambah pada wilayah masyarakat yang serat dengan budaya tradisional saja, melainkan juga merambah pada masyarakat modern. Berkaitan dengan hal ini, di berbagai wilayah penjuru dunia, mengerucut wilayah Indonesia, wujud aplikasinya ialah banyak ditemukannya kalangan kelompok eksekutif yang duduk bersama dalam suatu perkumpulan yang menamakan diri sebagai aliran thoriqoh atau tasawuf. Sehingga, ajaran dan konsep tasawuf para sufi menjadi perkara yang luar biasa di era globalisasi ini, meskipun telah banyak budaya barat yang diserap kalangan masyarakat. ${ }^{1}$

Modernitas yang merupakan hasil produksi dari budaya barat berkontribusi dalam ranah teknologi dan alat-alat berat yang canggih dalam ruang industri berdampak pada pandangan arah hidup manusia yang kehilangan tujuan prioritas, hidup materialistik menjadi dominan, sedangkan ruh kehidupan kosong semakin jauh dari tujuan. Prinsip idealitas hakikat hidup sebagai individu hancur. Alhasil, terbentuklah esensi baru yang menggeserkan esensi manusia ideal menjadi manusia materialistik, segala potensi ditinjau dari materi. Manusia pun tidak terhindar; lepas dari pedoman lalu terseret arus desekralisai dan dehumanisasi. Sehingga, terdapat berbagai problem akhlak dalam prainjau yang cukup jelas; baik ranah sosial yang terstruktur hingga spiritualitas individualistik.

Persoalan-persoalan diatas dalam dewasa tergambar dalam musibah virus corona yang terjadi di Indonesia. Dampak dari polemik ini menyebabkan pemerintah mengambil sikap yakni memberikan intruksi untuk masyarakat Indonesia supaya menjaga jarak, menjaga kebersihan dan isolasi bagi setiap warga yang baru datang atau mudik. ${ }^{2}$ Hal ini terjadi, sebagai bentuk antisipasi atas bertambahnya korban karena virus corona. Selain itu, hal ini dilandasi oleh para ahli kesehatan yang menyatakan bahwa virus corona merupakan penyakit yang mudah menyebar, bahkan menurut WHO wabah ini menular serempak meluas dan disebutkan bahwa virus corona ini merupakan wabah pandemik. ${ }^{3}$

\footnotetext{
${ }^{1}$ M. Laily Mansur, Ajaran dan Teladan Para Sufi, (Jakarta: PT. Raja Grafrindo, 1999), cet. 2, p. vvi.

2 Sesuai dengan arahan kementrian kesehatan kepada pada Pimpinan/Lembaga, Gubernur dan Bupati/Walikota seluruh Indonesia dalam surat edaran HK.02.01/MENKES/202/2020 tentang Protokol isolasi diri sendiri dalam penanganan virus corona. Lihat lebih lanjut https://www.jogloabang.com/kesehatan/se-hk0201menkes2022020-protokol-isolasi-diri-sendiripenanganan-corona-virus-disease, (diakses pada tanggal 06 April 2020).

3 Tedros Adhanom Ghebreyesus selaku Direktur Jenderal WHO. Lihat lebih lanjut https://katadata.co.id/berita/2020/03/17/melawan-virus-corona-dari-rumah, (diakses pada tanggal 06 April 2020).
} 
Bahayanya virus ini memberikan efek buruk pada individu. Terkhusus dalam pola fikir dan sikap. Banyak individu yang panik, ngeyel dan bandel terhadap intruksi dari pemerintah. Hal ini terlihat dalam fakta sosialnya yakni banyaknya warga yang masih melakukan kegiatan sehari-hari seperti biasanya, khususnya keluarga golongan menengah ke bawah, tanpa peraturan protokol kesehatan. Warga yang berada dalam golongan ini ialah para pedagang, ojek online dan yang lainnya yang menjadikan pekerjaan itu sebagai alat untuk mencari makan. Namun, meskipun demikian, penghasilan merekapun menurun dan bahkan sebagian dari pekerja merasa lebih sepi karena sebagian besar pelanggannya merupakan warga golongan menengah ke atas yang sudah belanja jauh-jauh hari untuk mempersiapkan diri dan keluarganya agar tidak keluar dari rumah. Bukan itu, saja polemik teologi juga masuk dalam permasalahan ini yakni terkait dengan akidah fatalistik. Dimana, golongan ini tidak menghiraukan instruksi pemerintah dan bahkan cenderung meremehkan virus corona dikarenakan keyakinan mereka bahwa virus corona tidak bisa menyebabkan seseorang mati atau menuju sengsara. Sehingga, aktivitas mereka tetap seperti biasanya meskipun dalam lingkungan tergolong zona merah.

Persoalan-persoalan di atas sangat serat dengan moralitas ${ }^{4}$ dalam Islam, terkhusus perihal tasawuf. ${ }^{5}$ Hal ini dikarenakan dalam dunia tasawuf terdapat ajaran-ajaran dan konsep yang serat dengan nilai-nilai moral Islami. Adapun salah satunya ialah Abu Hamid Al-Ghazali yang merupakan seorang ulama Islam dan esksitensinya diakui oleh kalangan sarjana dunia. ${ }^{6}$ Pemikirannya yang cerdas menjadikannya mendapatkan

${ }^{4}$ Moralitas Islam berobjek sentral pada manusia, artinya manusia memiliki kewajiban penuh. Berkaitan dengan hal tersebut, dalam Islam Manusia merupakan makhluk yang diperintah untuk menjadi wakil Tuhan. Bumi merupakan panggung dimana manusia bisa menemukan nama-nama Tuhan dan sifatsifat Tuhan. Dalam hal ini, manusia memiliki pilihan untuk menjadi dirinya secara sungguhan atau memegang erat kodratnya sebagai khalifah. Lihat Seyyed Hossein Nasr, Living Sufism, terj. Abdul Hadi, (Jakarta: Pustaka Firdaus, 1980), cet. 5, p. 36

${ }_{5}$ Ahmad Bangun Nst, (ed), Akhlak Tasawuf: Pengenalan, Pemahaman, dan Aplikasinya (Jakarta: PT RajaGrafindo Persada, tahun 2013), p. 7-8

${ }^{6}$ Dalam hal ini al-Ghazali merupakan satu-satunya diantara yang lain yang berhasil menyatukan antara syari'at, filsafat dan tasawuf. Perihal syari'at al-Ghazali terletak pada karyanya yakni Bidayah wa Nihayah. Lebih lanjut lihat Abu Hamid Al-Ghazali, Tuntunan Mencapai Hidayah Ilahi, terj. M. Fadlil Sa'd an-Nadwi, (Surabaya: al-idayah, 1998), p. 4. Sebelum al-Ghazali berhasil menentramkan atau menyatukan antara syari'at dan tasawuf, kedua kelompok itu saling bertolak belakang. Sehingga, problem demikian menjadikan al-Ghazali bertindak. Lihat lebih lanjut Abdul Qadir Mahmud, al-Falsafah al-Sufiyyah alIslam, (Kairo: Dar al-Fikr, 1993), p. 50. Al-Ghazali dengan keintelektualitasnya memiliki pengaruh yang luas sampai di luar kota kelahirannya. Banyak sekali karyanya, diantaranya ialah teologi, akhlak, al-Qur'an, hukum, filsafat, mistisisme. Karya-karyanya ini berpuncak pada 3 karyanya yang merujuk pada mistisisme, teologi dan filsafat. Diantaranya ialah, al-Munqiz min ad-Dalal, Ihya' 'Ulum ad-Din dan Kimiya' asSa'adah. Lihat lebih lanjut Hamid Dabasyi, The Heritagr of Sufism: Clasical Persian Sufism from its Origin To Rumi, terj. Gafna Raizha Wahyuni, (Yogyakarta: Pustaka Sufi, 2003), cet. 1, p. 17

Tribakti: Jurnal Pemikiran Keislaman

Volume 32, Nomor 1, Januari 2021 
beberapa gelar besar dari para cendekiawan, ${ }^{7}$ baik dari sarjana Islam maupun sarjana Barat. Adapun gelar besar yang di dapat oleh Ghazali dari para cendekiawan yang mengaguminya di antaranya ialah sebagai sang hujjatul Islam, ${ }^{8}$ sufi, filsuf dan ilmuwan. Sehingga, namanya melambung dalam literatur-literatur Islam. ${ }^{9}$

Bertolak dari permasalahan di atas, tulisan ini bertujuan mendeskripsikan, menjelaskan dan menganalisis untuk mengeksplor konsep makrifat dan ajaran tasawuf alGhazali juga internalisasinya dalam pandemik virus corona (covid-19) dewasa kini. Adapun beberapa kajian yang relevan dengan kajian penelitian ini di antaranya tinjauan literatur karya Yuliana. Dalam penelitiannya, disimpulkan bahwa coronavirus telah menginfeksi 90.300 an lebih orang per maret 2020. Virus ini menginfeksi saluran pernapasan. ${ }^{10}$ Kedua, Analisis Dampak Pandemi Virus terhadap Tingkat Kesadaran Masyarakat dalam Penerapan Protokol Kesehatan Karya Faura Dea Ayu Pinasti. Dalam penelitiannya disimpulkan bahwa berdasar kuesioner, masyarakat belum menerapkan protokol kesehatan dengan benar dan baik. Bahkan sebagian besar masyarakat tidak menjaga kebersihan tangan. ${ }^{11}$ Ketiga, Pandemi Covid-19 Repon Imun Tubuh dan Herd Immunity karya Rina Tri Handayani, dkk. Dalam penelitiannya, disimpulkan bahwa pandemi coronavirus terjadi karena ada penemuan dan mutasi baru dari virus SARS-CoV, menjadi sangat infeksius dan virulensi tinggi. ${ }^{12}$ Keempat, Dampak Pandemi Covid-19 terhadap Bisnis dan Eksistensi Platform Online karya Taufik dan Eka Avianti Ayunintyas. Dalam penelitiannya, disimpulkan bahwa pandemi coronavirus berakibat pada penurunan aktivitas bisnis offline namun bisa mengaktifkan bisnis melalui kegiatan online. $^{13}$

\footnotetext{
${ }^{7}$ Konsep nalar yang dibangun al-Ghazali dalam kalam tertuang dalam fasal I-XIII. Lihat lebih lanjut Nurcholish Madjid, Khazanah Intelektual Islam, (Jakarta: Bulan Bintang, 1985), cet. 2, p. 155-206

${ }^{8}$ Gelar yang al-Ghazali dapat setelah ia wafat, artinya umat Islam mengakui bahwa amal dan ilmu al-Ghazali selama hidupnya merupakan hujjah. Lihat lebih lanjut Hasbullah Bakry, Disekitar Filsafat Skolastik Islam, (Jakarta: Tintamas, 1961), cet. 3, p.49.

9 Abu Muhammad Iqbal, Konsep Pemikiran al-Ghazali tentang Pendidikan, (Madiun: Jaya Star Nine, 2013), p. 1.

${ }^{10}$ Yuliana, "Corona Virus Diseases (Covid-19); Sebuah Tinjauan Literatur", Wellness and healthy Magazine, 2 (1) (2020), p. 187-192.

${ }^{11}$ Faura Dea Ayu Pinasti, “Analisis Dampak Pandemi Corona Virus Terhadap Tingkat Kesadaran Masyarakat dalam Penerapan Protokol Kesehatan”, Wellness and healthy Magazine, 2 (1) (2020), p. 237249.

12 Rina Tri Handayani, dkk,"Pandemi Covid-19, Respom Imun Tubuh dan Herd Imunity”, Jurnal Ilmiah Permas; Jurnal Ilmiah STIKES Kendal, 10 (3) (2020), p. 373-380.

13 Taufik dan Eka Avianti Ayuningtyas, "Dampak Pandemi Covid-19 terhadap Bisnis dan Eksistensi Platform Online", Jurnal Pengembangan Wiraswasta, 22 (1) (2020), p. 21-32. 
Perbedaan penelitian ini dengan ketiga penelitian di atas ialah objek formal yang digunakan. Selain itu, basis daripada teori yang dipakai dalam ketiga penelitian di atas ialah 3 dari teori kesehatan, 1 dari teori bisnis. Sedangkan dalam penelitian ini menggunakan kacamata pemikiran agama seorang tokoh Islam dengan tasawufnya dan ajaran makrifatnya. Teori yang digunakan dalam penelitian ini ialah teori tasawuf dan makrifatnya Al-Ghazali. Sehingga, penelitian ini merupakan penelitian yang berbeda dengan ketiga penelitian di atas. Yaitu; Dampak Pandemi Covid-19 dalam Perspektif Gender Di Indonesia Karya Ikfina Chairani. Dalam penelitiannya, disimpulkan bahwa perempuan mengalami berbagai kesulitan yang lebih berat dalam pandemi Covid-19 dibandingkan laki-laki, baik dari sisi kesehatan maupun perekonomian. Pandemi juga mengakibatkan angka KDRT meningkat terhadap peremuan dan memperlambat penanggulangannya. ${ }^{14}$ Teori yang dipakai untuk melihat pandemi dalam kajian di atas ialah teori ilmu sosial mengkhusus pada gender. Sehingga, dipastikan berbeda dengan penelitian ini yang menggunakan teori tasawufnya imam Al-Ghazali. Konsep Makrifat Menurut al-Ghazali dan Ibnu 'Arabi; Solusi Antisipatif Radikalisme Keagamaan Berbasis Epistemologi karya A. Zaini Dahlan, dkk. Dalam penelitian ini disimpulkan bahwa melalui ajaran tafsir klasik, penuturan konsep makrifat dapat dipahami sebagai terbukanya segala rahasia ketuhanan dan ketersingkapan hukum Tuhan yang merajai. ${ }^{15}$

Penelitian di atas tidak sesuai dengan penelitian ini, dari segi objek yang dibidik dan pendekatan yang dipakai. Bahkan para pemfokusan basisnya pun berbeda. Sehingga, hasil dari penelitian ini berbeda dengan penelitian di atas.

Dari berbagai penelitian yang relevan terkait pandemi covid-19 dan al-Ghazali, dengan pengejawantahan perbedaan dan pembaruan yang ada dalam penelitian ini. Maka, dipastikan bahwa penelitian ini memiliki kebaruan dari penelitian-penelitian sebelumnya yang membahasa dan memiliki keterkaitan, dari segi objek yang dibidik maupun objek formal yang dipakai.

\section{Metode}

Jenis penelitian ini termasuk dalam penelitian kualitatif pustaka. Adapun cara pendekatannya ialah menggunakan cara deskripsi-analisis. Pendekatan deskripsi analisis

${ }^{14}$ Ikfina Chairani, "Dampak Pandemi Covid-19 dalam Perspektif gender di Indonesia", Jurnal Kependudukan Indonesia; Edisi Khusus Demografi dan Covid-19, (2020), p. 39-42.

15 A. Zaini Dahlan," Konsep Makrifat Menurut al-Ghazali dan Ibnu 'Arabi; Solusi Antisipatif Radikalisme Keagamaan Berbasis Epistemologi”, Kawistara, 3 (1) (2013), P. 69-78.

Tribakti: Jurnal Pemikiran Keislaman

Volume 32, Nomor 1, Januari 2021 
ialah pendekatan yang digunakan untuk menggambarkan data-data yang diperoleh melalui analisis ketat menggunakan kerangka teori dan disajikan dalam bentuk deskripsi. Selain itu, pendekatan dalam penelitian ini juga menggunakan kerangka teori tasawuf AlGhazali; dari konsep makrifat hingga ajaran-ajaran tasawuf yang dikembangkan.

Objek material dalam penelitian ini ialah pandemi covid-19, sedangkan objek formalnya ialah konsep makrifat dan ajaran tasawuf Al-Ghazali. Karya-karya Al-Ghazali dan berita covid-19 menjadi sumber data utama dalam penelitian ini. Sedangkan, kajiankajian yang terkait dengan covid-19 dan pemikiran Al-Ghazali menjadi sumber sekunder dalam penelitian ini; baik artikel, jurnal, data-data yang memuat referensi perihal konsep makrifat dan ajaran tasawuf Al-Ghazali.

Penelitian ini dilakukan pada bulan Maret-April 2020 dengan beberapa data terbaru yang disiarkan dalam beberapa media sosial dan web kesehatan. Pengumpulan data dilakukan melalui beberapa tahap, dari pemilihan, pemfokusan, penyederhanaan, gambaran hingga pengembangan dari data mentah yang tertuang dalam berita. ${ }^{16}$ Setelah data direduksi dan dibuang beberapa poin yang tidak perlu kemudian data disajikan berupa sekumpulan informasi dalam bentuk deskripsi, yakni informasi yang diplih kemudian ditampilkan dengan narasi, sehingga masuk ketahap berikutnya. ${ }^{17}$

Langkah selanjutnya ialah penarikan kesimpulan dan verifikasi. Penarikan kesimpulan yang diharapkan ialah menemukan temuan baru dalam penelitian ini. Setelah itu, pada tahap terakhir ialah menarik kesimpulan dari data yang telah dianalisis dan dedeskripsikan. Sehingga, akan didapatkan kesimpulan akhir tentang internalisasi tasawuf Al-Ghazali dalam pandemik Covid-19.

\section{Hasil Dan Pembahasan}

\section{Konsep Makrifat al-Ghazali}

Konsep makrifat ${ }^{18}$ al-Ghazali disebabkan oleh 3 perkara, di antaranya ialah karena ia sebagai penuntut ilmu yang terus saja memiliki keinginan untuk selalu mencari pengetahuan. Kemudian ia juga mengkonstruk dirinya sebagai seseorang yang diciptakan

\footnotetext{
${ }^{16}$ Emzir, Metodologi Penelitian Kualitatif Analisis Data, (Jakarta: PT. RajaGrafindo Persada, 2012), hlm. 129-130.

17 Sugiyono, Metodologi Penelitian Pendidikan PendekatanKuantitatif, Kualitatif dan $R$ \& D, (Bandung: Alfabeta, 2007), hlm. 341.

18 Abu Hamid al-Ghazali, Samudera Pemikiran al-Ghazali, (Yogyakarta, Pustaka Sufi, 2002), p. 221 
dengan tugas menghidupkan kembali ruh agama ${ }^{19}$ (mistisisme dan syari'at). ${ }^{20}$ Yang ketiga, ia memiliki karakter ingin terus mencari hakekat ${ }^{21}$ dengan disertai semangat yang luar biasa. ${ }^{22}$

Al-Ghazali mengungkapkan bahwasanya makrifat itu jalan untuk menuju cinta, artinya al-Ghazali memberikan pandangan bahwa seseorang tidak dapat mencintai Tuhannya apabila dirinya tidak kenal atau dekat dengan Tuhannya. Dalam artian lain konsep makrifat sebelum mahabbah menunjukkan bahwa sufi merupakan orang-orang khusus yang dekat dengan Tuhan dan didekati oleh Tuhan. ${ }^{23}$ Dalam hal ini sesuai dengan pendapat Zunnun al-Misri bahwa manusia mengetahui Tuhan karena Tuhan memperkenalkan dirinya ${ }^{24}$, jika tidak, manusia tidak akan dapat mengetahui Tuhan. ${ }^{25}$

Selain Zunnun al-Misri, al-Ghazali sependapat dengan al-Qusyairi dalam pandangan kemakrifatan yakni bahwa dalam mencapai makrifat manusia harus memaksimalkan alat mereka. Alat tersebut ialah, qalb (mengetahui sifat-sifat Tuhan), ruh (untuk mencintai Tuhan) dan sir (untuk melihat Tuhan). Dalam hal ini al-Ghazali menambah satu lagi alatnya yakni akal. ${ }^{26}$ Kaum sufi dikenal dengan golongan sir (mereka

${ }^{19}$ Harun Nasution, Islam Ditinjau Dari Berbagai Aspek Jilid I, (Jakarta: UI Press, 1985), p. 46.

${ }^{20}$ Mistisisisme lebih dominan berada dalam wilayah kebudayaan Islam. upaya yang dilakukan oleh orang orang persia untuk melahirkan pintu religius ruhani dalam Islam. Lihat Gerhard Bowering, The Heritagr of Sufism: Clasical Persian Sufism from its Origin To Rumi, terj. Gafna Raizha Wahyuni, (Yogyakarta: Pustaka Sufi, 2003), cet. 1, p. 1

${ }^{21}$ Sufi merupakan seorang yang menggapai sebuah hakekat dengan jalan cinta dan istiqomah. Untuk menuju hakekat seseorang tidak boleh cacat melainkan harus sempurna. Javad Nurbakhsh, In The Paradise of the Sufis, terj. Zaimul Am, (Jakarta: Zaman, 2016), cet. 1, p. 12. Javad Nurbakhsh dan Seyyed Hossein Nasr, The Heritagr of Sufism: Clasical Persian Sufism from its Origin To Rumi, terj. Gafna Raizha Wahyuni, (Yogyakarta: Pustaka Sufi, 2003), cet. 1, p. 51. Al-Ghazali merupakan seorang sufi, intelektual yang terus saja mencari hakekat. Lihat Sobhi Rayan,"Al-Ghazali's Method of Doubt", Middle East Studies Association of North America (MESA): Middle East Studies Association Bulletin, 38 (2) (2004), pp. 162173 lihat lebih lanjut di link https://www.jstor.org/stable/23062806

22 Victor Said Basil, Manhaj al-Bahtsi'an al-Ma'rifah 'inda al-Ghazali, terj. Ahmadie Thaha, (Jakarta: Pustaka Panjimas, 1990), cet. 1, p. 12.

${ }^{23}$ Harun Nasution, Falsafat dan.., p. 59

${ }^{24}$ Ucapan ini alurnya hampir mirip dengan ungkapan Imam Ghazali bahwa manusia sebagai seorang hamba itu seperti buruh, ia tidak boleh mengatasi apa saja yang diluar dari perintah atau kuasa majikannya. Lihat Hussein Bahreisj, Ajaran-ajaran Akhlak Imam Ghazali, (Surabaya: Al-ikhlas, t.th), p. 36

25 Zunnun al-Misri dikenal sebagai bapak dalam kelompok makrifat. Pandangannya terhadap makrifat sangat jeli dan logis. Ia membagi 3 golongan pengetahuan dalam diri manusia. yang pertama golongan awam yakni mereka yang mengetahui Tuhan Esa melalui dua kalimat syahadat yang di ucapkan. Kedua, golongan khusus atau ulama yakni mereka yang mengetahui Tuhan melalui proses nalar tanpa taklid semata. Yang ketiga, golongan mistisisme Islam atau sufistik yakni golongan yang mengetahui Tuhan melalui perantara hati sanubari, artinya Zunnun al-Misri menegaskan bahwasanya dalam mengetahui Tuhan seorang manusia sudah memiliki keistimewaan tersendiri, terkhusus bagi mereka yang benar-benar berusaha menemukan hakekat. Lihat Harun Nasution, Falsafat dan.., p. 60. Berkaitan dengan hal tersebut sesuai dengan ungkapan Imam Ghazali terkait pembagian golongan manusia yakni bahwa manusia itu terdapat 3 bagian, awam, khusus dan pakar debat dan kurios. Abu Hamid al-Ghazali, Neraca Kebenaran, terj. Kamran As'ad irsyady, (Yogyakarta: Pustaka Sufi, 2003), cet. 1. P. 80.

${ }^{26}$ Abdul Ghofur,"Tasawuf Ghazali: Landasan Psikologi Pendidikan Islam", Jurnal Islam Nusantara 2 (1) (2018), p. 1-16.

Tribakti: Jurnal Pemikiran Keislaman

Volume 32, Nomor 1, Januari 2021 
yang dapat melihat Tuhan). Berkaitan dengan hal tersebut, bagi Ghazali makrifat ialah mengetahui rahasia Allah dan mengetahui segala peraturan yang ada dari Tuhan. Bukan itu saja, Ghazali juga menegaskan bahwasanya makrifat dan cinta merupakan puncak kesufian. Selain itu, pengetahuan yang didapat dengan jalan makrifat memiliki kedudukan lebih tinggi daripada pengetahuan yang didapat dari nalar akal. ${ }^{27}$

Ketika seorang hamba telah mencapai puncaknya yakni makrifat dan mahabbah, maka yang akan ia raih selanjutnya ialah kebahagiaan yang abadi. ${ }^{28}$ Berkaitan dengan hal tersebut, al-Ghazali merangkumnya dalam kitabnya yakni kimiyaus sa'adah. Baginya kenikmatan dan bahagia tertimbang oleh nafsu yang kemudian akan hangus sesudah mati. Sedangkan, kenikmatan dan bahagia ialah ketika ciptaan melihat pencipta yang akan abadi meski telah hangus; bahkan akan terus menumpuk banyak karena terpisah dari kegelapan nafsu. ${ }^{29}$

\section{Ajaran Tasawuf al-Ghazali}

Ajaran tasawuf Ghazali ${ }^{30}$ merupakan perpaduan antara ilmu kalam ${ }^{31}$, tasawuf dan syari'at. ${ }^{32} \mathrm{Al}$-Ghazali dikenal sebagai sufi yang mampu mendudukkan tasawuf, ${ }^{33}$ ilmu

27 Harun Nasution, Falsafat dan.., p. 61-62. Dalam karyanya tahafut al falasifah, al-Ghazali menawarkan senjata untuk menambah kekuatan nomosentris dalam masyarakat Islam untuk melawan nalar yang secara otoriter digunakan untuk klaim kebenaran melalui logis atau melalui eksperimen. Lihat juga Hamid Dabasyi, The Heritagr.., p. 6

28 Puncak dari pencarian al-Ghazali. Lihat Nurcholis Madjid, Kaki Langit Peradaban Islam, (Jakarta: Paramadina, 1997), p. 179.

29 Abu Hamid al-Ghazali, Al-Mahabbah wa Minhajul Abidin, terj. Abdullah bin Nuh, (Jakarta: Tintamas, 1992), cet. 10.

${ }^{30}$ Ketenangan al-Ghazali didapatinya ketika ia telah melewati berbagai liku pergolakan dalam keilmuan. Lihat lebih dalam Abu Hamid Al-Ghazali, Al-Munqidz min Adh-Dhalal, (Al-Maktabah AsySyibiah, Berut), p. 75.

${ }^{31}$ Karya-karya al-Ghazali dalam ilmu kalam dan filsafat yakni Maqashidu al-falasifah, Tahafut alfalasifah dan al-Ma'rifatul 'aqliyah. Lihat lebih lanjut Thawil Akhyar Dasoeki, Sebuah Kompilasi Filsafat Islam, (Semarang: Dias Utama Semarang, 1993), cet. 1, p. 58-59. Konsep nalar yang dibangun dalam kritikannya akan filsafat dan kausalitas yang dibangun para filsuf sebelumnya. Lihat Edward Omar Moad,"Al-Ghazali on Power, Causation, and 'Acquisition", University of Hawai'i Press Philosophy East and West, 57 (1) (2007), pp. 1-13. Lebih lanjut di link https://www.jstor.org/stable/4488073. Lihat juga Ilai Alon,"Al-Ghazālī on Causality", Journal of the American Oriental Society, 100 (4) (1980), pp. 397-405. Lebih lanjut lihat di link https://www.jstor.org/stable/602085

32 Karya-karyanya dalam ilmu tasawuf dan syari' at yakni Ihya 'Ulumiddin, Mizzanul 'amal. Kimiya'us Sa'adah, Minhajul Abidin, Kitabul A'ba'in, Tibul Masbuk fi Nashiehat al Mulk, Musthafa fil Ushul, Mishkatul Anwar, Munqidz min ad-Dhalal, Ayyuhal Walad, Adab fid Diin, Risalah Laduniyah dll. Lihat lebih lanjut Thawil Akhyar Dasoeki, Sebuah Kompilasi.., p. 60-61. Adapun pendapat lain bahwa karya al-Ghazali yang diwariskan menurut Saiful terdapat 72 karya tulis. Lebih lanjut lihat Saiful Anwar, Filsafat Ilmu al-Ghazali, (Bandung: CV Pustaka Setia, 2007), p. 69.

33 Tasawuf al-Ghazali merupakan tasawuf sunni. Ia juga menjauhkan tasawufnya dari paham ketuhanan Aristoteles, seperti emanasi dan penyatuan, sehingga dikatakan bahwa tasawuf al-Ghazali benar benar bercorak Islam. Lihat Abu al- Wafa' al-Ghanimi al-Taftazani, Sufi Dari Zaman ke Zaman, (Bandung: Pustaka, 1997), p. 156 
kalam $^{34}$ dan syariat dalam satu jalan, ${ }^{35}$ artinya pergolakan ${ }^{36}$ yang terjadi antara syari'at dan tasawuf sejak sebelumnya berhasil ia tengahi ${ }^{37}$ dengan ajaran-ajarannya yang serat dengan ilmu kalam dan syari'at. ${ }^{38}$ Dalam Ihya, ${ }^{39}$ al-Ghazali mengulas berbagai paham dalam tasawuf ${ }^{40}$ dengan melakukan sinergitas melalui syariat. Adapun hasilnya idlah terbentuklah tasawuf akhlak. Di antaranya meliputi taubat, sabar, fakir, zuhud, tawakal, mahabbah, dan rida. ${ }^{41}$ Adapun penjelasannya sebagai berikut:

Taubat, merupakan jalan awal untuk mendaki makrifat. Taubat identik dengan penyesalan seorang hamba atas segala perbuatannya. Pertaubatan bisa dilakukan jika seseorang instropeksi diri kemudian ia selalu mengoreksi dirinya dan menemukan kekurangan. Langkah untuk membuka hati seorang yang ingin makrifat ialah taubat dari segala dosa. Bagi al-Ghazali kunci awal untuk dicintai oleh Allah sebagai langkah awal

${ }^{34}$ Keramaian dalam dunia filsafat Islam terkhusus mistisisme kalam al-Ghazali dan Ibnu Rusyd. Lihat J. Janssens,"Filosofische Elementen in De Mystieke Leer Van Al-Ghazali (Ihyâ, 31-36)", Peeters Publishers: Tijdschrift voor Filosofie, 50ste Jaarg, (2) (1988), pp. 334-342. Lihat lebih lanjut di link https://www.jstor.org/stable/40885623. Dalam kalamnya, konsep silogisme merupakan salah satu yang diterapkan al-Ghazali dalam membuat gagasan atau kesimbulan dari suatu perkara. Lihat Henrik Lagerlund,"Al-Ghazālī on the Form and Matter of the Syllogisms", Brill: Vivarium, Special Issue: Aristotelian Logic East and West, 500- 1500: "On Interpretation" and "Prior Analytics" in Two Traditions, 48 (1/2) (2010), pp. 193-214. Lihat lebih lanjut di link https://www.jstor.org/stable/41963861. Kontribusi al-Ghazali dalam pemikiran teologi Islam terkhusus takdir, yang didialogkan dalam kajian al-Qur'an dan Alkitab. Lihat Matthew Levering,"Providence and Predestination in Al-Ghazali”, Wiley: New Blackfriars, 92 (1037) (2011), pp. 55-70. Lihat lebih lanjut di link https://www.jstor.org/stable/43251500

${ }^{35}$ Lihat Amin Abdullah, Studi Agama; Normativitas atau Historisitas, (Yokyakarta: Pustaka Pelajar, 1996), p. 267. Pengakuan eksistensi tasawuf oleh kalangan umat Islam juga para sarjana Barat. Lihat lebih lanjut Fazlur Rahman, Islam, (Bandung: Penerbit Pustaka, 2000), p. 22.

36 Keseimbangan al-Ghazali dalam teologi yang tidak condong pada aliran kanan dan kiri menjadikannya berhasil teguh dalam kesufian suni. Lihat Ovamir Anjum,"Cultural Memory of the Pious Ancestors ("Salaf") in al-Ghazālī’, Brill: Cultural Memory and Islam, 58 (2/3) (2011), pp. 344-374. Lebih lanjut lihat di https://www.jstor.org/stable/23045880. Lihat juga Muhammad Zurkani Jahja, Teologi Ghazali; Pendekatan Metodologi, (Yokyakarta: Pustaka Pelajar, 1996), p. 51. Lihat juga Nurcholish Madjid, Islam Kemordenan dan Keindonesiaan, (Jakarta: Mizan, 1988), cet. 2, p. 283.

37 Peranannya dalam Islam sangat luar biasa. Al-ghazali merupakan wakil dari Islam yang mewujudkan Islam melalui konsep cinta perdamaian dan cinta pengetahuan. Lihat lebih lanjut Ayi Sofyan, Kapita Selekta Filsafat, (Bandung: CV Pustaka Setia, 2010), cet. 1, p. 253.

38 Al-Ghazali dikenal dengan nama populer dari madzab tauhid dan fikih yang dipegangnya, namanya direkatkan dengan 2 tokoh yakni Imam Syafi'i dan Abu Hasan Asy'ari. Lihat Muhammad alBaqir dalam "Pengantar Penerjemah" Abu Hamid al-Ghazali, Asrar Ash-Shalah wa Muhimmatuha, (Bandung: Karisma, 1996), cet. 14, p. 5. Lihat juga Rosihon Anwar dan Mukhtar Solihin, Ilmu Tasawuf, (Bandung: Pustaka Setia, 2000), p. 53.

39 Karyanya ini dipandang oleh para sarjana Barat sebagai kontribusi al-Ghazali terbesar pada masanya, dimana karyanya tersebut bersifat mekanis. Lihat Brian M. Hauglid,"Al-Ghazali, a Muslim Seeker of Truth", Brigham Young University: A Special Issue on Islam, 40 (4) (2001), pp. 89-96. Lihat lebih lanjut di link https://www.jstor.org/stable/43044282

${ }^{40}$ Dalam hal ini, adapun keutamaan akhlak dari berbagai akhlak yang dimaktubkan dalam Ihya 'ulumiddinnya yakni kebijaksanaan, keberanian, pemeliharaan diri dan keseimbangan. Lihat lebih lanjut Kasron Nst,'Konsep Keutamaan Akhlak Versi Ghazali”, HIJRI: Jurnal Manajemen Pendidikan dan Keislaman, 6 (1) (2017), p. 106-1018.

${ }^{41}$ Mulyadhi Kartanegara, Menyelami Lubuk Tasawuf, (Jakarta: Erlangga, 2006), p. 202.

Tribakti: Jurnal Pemikiran Keislaman

Volume 32, Nomor 1, Januari 2021 
untuk dekat ialah menyesali dosa-dosanya, kemudian meninggalkannya dengan niat dan tujuan, juga meninggalkan dosa kebiasaan yang dahulu dikerjakannya. ${ }^{42}$ Selain itu, alGhazali juga mengungkapkan bahwa salah satu jalan bertasawuf ialah menyucikan diri dari segala yang tercela. Caranya ialah melawan tantangan yang menghambat kesucian diri. $^{43}$

Sabar, merupakan jalan kedua yang menganjurkan untuk selalu tabah dan kuat dalam segala perihal dunia baik fisik yang mengganggunya. Sabar merupakan tindakan yang diimplementasikan. Umumnya ada ujian yang menghadang, baik dari beberapa penyakit hingga hujatan sesama manusia. Adapun sabar yang dilekatkan dengan mempertahankan diri dari harapan dalam keinginan yang kuat. ${ }^{44}$ Selain itu, secara lebih detail yakni sabar dari godaan ${ }^{45}$ dunia dan seisinya, makhluk Tuhan, setan dan hawa nafsu, artinya sabar bisa dikuatkan sikap raja ${ }^{46}$ juga khauf. $^{47}$

Kefakiran, semua makhluk itu membutuhkan Pencipta untuk melanjutkan kehidupannya. Untuk itu maka, manusia berada diantara ruang penderitaan dan bahagia. Kefakiran yang dimaksud al-Ghazali cenderung ke arah qona'ah yakni merasa cukup dan selalu dalam keseimbangan. Dalam hal ini, diartikan sebagai seseorang yang membutuhkan sesuatu, namun ketika sesuatu yang dibutuhkan itu ada ia biasa aja dan ketika sesuatu tidak ada ia juga biasa saja. ${ }^{48}$

Zuhud, zuhud hakekatnya ialah membelakangkan semua mata dari dunia, artinya tidak mempedulikan ihwal kaya juga miskin, mulia juga hina, dipuji hingga dicela, karena

${ }^{42}$ Abu Hamid al-Ghazali, Mukasyafah al-Qulub: al-Muqarrib ila Hadhrah 'allam al-Ghuyub fi 'Ilm al-Tasawuf, terj. Deny Riana, (Bandung: MQ Publishing, 2004), cet. 1, p. 37-50.

${ }^{43}$ Abu Hamid al-Ghazali, Al-Munqidz min Adh-Dhalal, (Beirut: Al-Maktabah Asy-Syibiah, 1408H), p. 75. Dalam karyanya ini al-Ghazali mengungkapkan bahwa ia mempelajari karya-karya sufi sebelumnya seperti al-Muhasibi, Abu Thalib al-Maliki, al-Junaydi, Shibli dan Abu Yazid al-Bustami. Lihat Margaret Smith,"The Forerunner of al-Ghazālī", Cambridge University Press: The Journal of the Royal Asiatic Society of Great Britain and Ireland, (1) (1936), pp. 65-78. Lebih lanjut lihat di link https://www.jstor.org/stable/25182038

${ }^{44}$ Dalam hal ini bisa diwujudkan seperti demikian yakni tidak mencaci maki atau mengomel karena caci maki dan omelan merupakan salah satu hasil dari tindakan yang timbul dari amarah. Secara batin, amarah menimbulkan dendam, dengki dan mencemarkan nama baik. Rasa senang bila orang yang menjadi objek amarah terkena musibah. Lihat Abu Hamid al-Ghazali, Kitabuabul Arba'iin fii Ushuluddin terj. Moh. Syamsi Hasan dan Abu Shofia, (Surabaya: Ampel Mulia, 2003), cet. 1, p. 30. Lihat juga Abu Hamid alGhazali, Marah, Dendam dan Kasih Sayang, terj. Immun El-blitary, (Surabaya: Al-Ikhlas, 1980), p. 22.

${ }^{45}$ Orang yang mudah marah dikarenakan lemahnya dalam tauhid. Menjujung asas-asas perdamaian dan kedamaian sebagai wujud humanisme dalam Islam. Lihat Abu Hamid al-Ghazali, Marah, Dendam dan Kasih Sayang, terj. Immun El-blitary, (Surabaya: Al-Ikhlas, t.th), p. 29

${ }^{46}$ Abu Hamid al-Ghazali, Ihya' Ulum al-din jilid VII, terj. Ismail Yakub, (Jakarta: CV Faizan, 1985), p. 66-68.

${ }^{47}$ Lebih dalam dijelaskan bahwa terdpat beberapa musuh hati. Lebih lanjut lihat Muhammad Hilmi Jalil, dkk, "Konsep Hati Menurut al-Ghazali”, Jurnal Reflektika 11 (11) (2016), pp. 59-71

${ }^{48}$ Moh. Saifullah al-Aziz Senali, Risalah Memahami Ilmu Tasawuf, (Surabaya: Terbit Terang, 1998), P. 122-123. 
dekat sekali dengan Tuhan dan percaya akan kehikmatan yang diberiNya. ${ }^{49}$ Ada beberapa ciri zuhud bagi Ghazali, di antaranya (1) biasa saja dalam permasalahan harta dunia (tidak terlalu peduli juga tidak terlalu meremehkan) posisinya ditengah (2) tidak ada perbedaan antara celaan dan hinaan, semuanya sama (3) dekat dengan Allah dan memprioritaskan Allah semata-mata.

Tawakkal, pada umumnya tawakal merupakan fase dimana manusia telah berusaha dan terus berusaha kemudian ia menyerahkan segala ketentuan dan kejadian kepada yang dipercayanya yakni Allah. Tawakkal diartikan sebagai juga sebagai konsep seorang beriman yang takwa dalam wujudnya sebagai aplikasi dari ilmu. ${ }^{50}$ Hakekat tawakkal ialah memasrahkan segala urusan sepenuhnya kepada Allah dan menyucikan upaya beserta perencanaan yang disertai dengan kesombongan daya. ${ }^{51}$

Mahabah, fase ini merupakan fase dimana seorang hamba mengaitkan sesuatu dengan Allah, artinya segala hal yang ia jadikan objek cintanya itu dengan alasan karena Allah. Al-Ghazali memberi garis bawah bahwa mencintai Allah harus melalui perkenalan atau makrifatullah. Menurut al-Ghazali melalui makrifat seorang hamba dapat mencintai Tuhannya. ${ }^{52}$

Rida, fase ini sangat sarat dengan fase mahabbah. Hal ini dilandasi bahwa ketika rasa mahabbah kepada pencipta mendaging dalam sanubari, maka yang timbul hanya kebahagiaan dan rasa senang. Sebab, semuanya berasal dari rahmat Tuhan. Meskipun, hal tersebut bagi siapapun menyakitkan juga luka, bagi orang yang dalam tahapan ini, ia akan senang dan bahagia sebab hal tersebut.

Setelah berhasil menempuh tahapan atau maqam yang sebelumnya, dan telah berhasil mengamalkan berbagai macam ibadah, maka idealnya sampai pada rasa syukur, mengharapkan rida Allah melalui pujian-pujian yang memang tertuju padaNya. Dalam hal ini, kita wajib bersyukur dan mengharapkan ridanya. Pujian dan ungkapan syukur yang diikrarkan secara mantap memiliki nilai spiritual yang tinggi. Bagaimana tidak, berbagai pelajaran terselubung dalam makna rasa syukur dan pujian tersebut. ${ }^{53}$

${ }^{49}$ Moh. Saifullah al-Aziz Senali, Risalah Memahami.., p. 128.

${ }^{50}$ Menurut al-Ghazali bahwa ilmu itu adalah permata dan lebih utama dari segalanya (taubat, ibadah, takwa, dll) akan tetapi tidak boleh meninggal dari ke semua itu, kita harus bertaubat disertai ilmu, kita harus beribadah disertai ilmu, dan kita harus bertakwa disertai juga dengan ilmu. Lihat Abu Hamid al-Ghazali, Minhajul Abidin Petunjuk Ahli Ibadah, terj. Abul Hiyadh , (Surabaya: Mutiara Ilmu, 1995), cet. 1, p. 17

51 Abdul Qadir al-Jailani, Babul Tashawwuf fii al-Ghunyah Lithalibi Thariq al-Haqq,terj. Aguk Irawan, (Jakarta: Zaman, 2012), cet. 1, p. 137.

52 Fungsi dari makrifat menurut al-Ghazali ialah sebagai petunjuk yang berfungsi membimbing tujuan hidup manusia semat-mata untuk Allah. Lihat Abu Hamid al-Ghazali, Mukasyafah al-Qulub.., p. 1. ${ }^{53}$ Abu Hamid al-Ghazali, Minhajul Abidin.., p. 351-354

Tribakti: Jurnal Pemikiran Keislaman

Volume 32, Nomor 1, Januari 2021 


\section{Internalisasi Tasawuf al-Ghazali dalam Pandemik Covid-19}

Internalisasi ialah penanaman suatu nilai ke dalam jiwa individu sehingga tercermin sikap dan perilaku dari nilai yang ditanamkan. ${ }^{54}$ Dengan demikian, maka internalisasi tasawuf al-Ghazali dalam pandemik covid-19 ialah menanamkan nilai-nilai ajaran tasawuf al-Ghazali dan konsep makrifatnya ke dalam jiwa individu dengan tujuan tercerminnya sikap dan perilaku sesuai dengan ajaran tasawuf dan makrifat al-Ghazali di masa pandemik covid-19.

Pada ajaran tasawuf dan makrifat al-Ghazali, terdapat 3 tingkatan yang dimunculkan. Ketiga tingkatan ini ialah awam, khusus dan puncak. Golongan awam ialah golongan yang memahami sesuatu dari satu sudut pandang, golongan khusus itu memahami sesuatu berdasarkan kelogisan dan golongan puncak ialah golongan yang memahami sesuatu dengan hati sanubari.

Dengan klasifikasi dan batasan demikian, maka golongan awam diisi mereka yang tidak memahami sesuatu dari sudut pandang, wabah covid-19 akan dipahami sebagai sesuatu yang serius dan tidak boleh dipermainkan. mereka yang menganggap bahwa covid-19 ini sama dengan penyakit-penyakit yang ada, mereka akan mengacuhkan dengan alasan bahwa hanya Tuhan yang mampu mematikan. Istilah lain dari golongan awam model seperti ini dikenal dengan fatalistik bertauhid. Golongan awam model kedua cenderung lebih tidak mempedulikan seganas apapun penyakitnya, mereka akan tetap beraktifitas seperti biasanya. Sehingga, tidak ada upaya untuk memikirkan orang lain ataupun bahayanya covid ini untuk dirinya dan orang lain. Dalam istilah al-Ghazali golongan awam ini cenderung lebih tawakkal dan menjaga diri sekaligus fakir (butuh bantuan).

Adapun golongan yang memikirkan orang lain juga memikirkan dirinya. Menurut Imam Ghazali golongan ini merupakan golongan khusus. Dalam pandemik covid golongan ini dapat digambarlan seprti para influencer dan lain sebagainya yang peduli akan korban covid-19. Gologan khusus ini diisi oleh mereka yang sadar dengan pengetahuannya bahwa virus ini sangat bahaya sehingga harus benar-benar berhati-hati, di lain sisi mereka juga sadar mereka hidup di dalam masyarakat yang di dalamnya ditinggali oleh berbagai macam kalangan. Sehingga, apapun yang terjadi mereka harus ikut andil dalam upaya membantu korban covid-19 yang membutuhkan. Mereka yang

${ }^{54}$ E.Mulyasa, Manajemen Pendidikan Karakter, (Bandung: Rosda, 2012), hlm.147. 
berada di dalam golongan ini ialah yang selalu berpikir logis, optimis dan teliti yang tentunya dibersamai dengan ilmu yang mumpuni. Sehingga, mereka bisa menempatkan dirinya dalam situasi covid-19 bahkan menjadi agen pembantu yang menawarkan edukasi gratis, penyalur makanan gratis, dan pembantu korban-korban yang terus bertambah.

Sedangkan dalam golongan puncak berisi para donatur yang membantu korban covid-19 dan para petugas medis. Hal ini dilandaskan pada pemahaman mereka akan covid-19 sebagai sebuah bencana kemanusian, dan banyak korban yang berjatuhan juga banyak perusahaan yang tutup, sehingga banyak pengangguran yang tidak berpenghasilan, bahkan sebagian ada beberapa yang kelaparan. Di lain sisi banyak korban yang terus bertambah, artinya peluang untuk terkena semakin tinggi. Namun, meskipun demikian parahnya dan terus saja bertambah. Mereka yang berada di golongan ini menghadirkan sebuah nurani dari hati sanubarinya untuk mendonasikan sebagian hartanya juga mendonasikan waktu istirahatnya. Golongan puncak merupakan golongan yang diisi oleh mereka yang memahami covid dengan hati sanubari.

Selain itu, dari ajaran al-Ghazali seorang manusia yang tengah berada dalam wabah yang pandemik secara global, sudah seharusnya bertaubat dan meninggalkan segala perbuatan keji yang berdosa. Karena dampak dari covid-19 menyebabkan sebagian pemerintah menganjurkan untuk tetap di rumah sampai batas waktu yang belum ditentukan. Bukan itu saja, dari hal ini juga manusia seharusnya bersabar akan berbagai problem yang hadir sebagai dampak dari virus corona.

Bukan itu saja, hadirnya virus corona mengajarkan manusia harus memikirkan kembali tentang perihal keduniawian. Sehingga, mau tidak mau manusia harus mempertimbangkan segala halnya, termasuk mencari hikmah di balik semua yang terjadi. Adapun gambarannya yakni meningkatnya ketakutan akan Tuhan dan butuh akan Tuhan. Selain itu juga, secara tidak langsung manusia juga diajarkan untuk zuhud, yakni meninggalkan perkara dunia yang di dalamnya berisi duri yang dapat membuatnya menyesal dikemudian hari lalu hanya menuju pada Allah.

Upaya-upaya yang dilakukan manusia juga menurut al-Ghazali merupakan bentuk aplikasi dari pengetahuan dan keilmuan mereka. Untuk itu, maka sudah sepatutnya manusa mengenal Tuhan-Nya sehingga mereka dapat selalu dalam keadaan bersyukur dan mengingat Tuhan-Nya dengan tujuan agar selalu dekat dan didekati oleh Tuhannya. Karena kepanikan dan ketakutan yang membekas merupakan bentuk kejauhan makhluk 
dari Tuhannya. Sehingga, bagi al-Ghazali manusia sudah sepatutnya mempertimbangkan segala hal terutama dengan ilmu dan pengetahuan untuk mencari hakekat kebenaran.

\section{Kesimpulan}

Internalisasi tasawuf Imam al-Ghazali dalam pandemik covid-19 merupakan cara yang tepat. Dalam tasawufnya al-Ghazali menawarkan bagaimana seharusnya individu bersikap dan bertindak dalam setiap kehidupan, khususnya dalam problematika besar seperti pandemik covid-19 dewasa kini. Di antaranya meliputi taubat, sabar, fakir, zuhud, tawakal, mahabbah, dan rida. Selain itu, al-Ghazali juga telah membagi tawaran kema'rifatan ke dalam 3 bagian. Setiap bagian, memiliki kedudukan sendiri-sendiri, dari awam, khusus, hingga puncak. Tawaran al-Ghazali merupakan upayanya dalam mendeskripsikan bagaimana semestinya manusia mendekatkan dirinya pada Tuhan. 3 tingkatan makrifatnya yang diadopsi dari Dzunnun al-Misri merupakan gambaran bagaimana seharusnya manusia berupaya mendekatkan diri kepada Tuhan, meski ditengah pandemik covid-19. 


\section{Daftar Pustaka}

Abdullah, Amin. Studi Agama; Normativitas atau Historisitas, Yokyakarta: Pustaka Pelajar, 1996

Abu Hamid al-Ghazali, Mukasyafah al-Qulub: al-Muqarrib ila Hadhrah 'allam alGhuyub fi 'Ilm al-Tasawuf, terj. Deny Riana, Bandung: MQ Publishing, 2004

al-Baqir, Muhammad dalam "Pengantar Penerjemah" Abu Hamid al-Ghazali, Asrar AshShalah wa Muhimmatuha, Bandung: Karisma, 1996

al-Ghazali, Abu Hamid. Ihya' Ulum al-din jilid VII, terj. Ismail Yakub, Jakarta: CV Faizan, 1985

al-Ghazali, Abu Hamid. Marah, Dendam dan Kasih Sayang, terj. Immun El-blitary, Surabaya: Al-Ikhlas, 1980

al-Ghazali, Abu Hamid. Marah, Dendam dan Kasih Sayang, terj. Immun El-blitary, Surabaya: Al-Ikhlas, t.th.

al-Ghazali, Abu Hamid. Minhajul Abidin Petunjuk Ahli Ibadah, terj. Abul Hiyadh, Surabaya: Mutiara Ilmu, 1995

al-Ghazali, Abu Hamid. Al-Mahabbah wa Minhajul Abidin, terj. Abdullah bin Nuh, Jakarta: Tintamas, 1992

al-Ghazali, Abu Hamid. Al-Munqidz min Adh-Dhalal, Beirut: Al-Maktabah Asy-Syibiah, $1408 \mathrm{H}$

al-Ghazali, Abu Hamid. Kitabuabul Arba 'iin fii Ushuluddin terj. Moh. Syamsi Hasan dan Abu Shofia, Surabaya: Ampel Mulia, 2003

al-Ghazali, Abu Hamid. Neraca Kebenaran, terj. Kamran As'ad Irsyady, Yogyakarta: Pustaka Sufi, 2003

al-Ghazali, Abu Hamid. Samudera Pemikiran al-Ghazali, Yogyakarta, Pustaka Sufi, 2002

Al-Ghazali, Abu Hamid. Tuntunan Mencapai Hidayah Ilahi, terj. M. Fadlil Sa'd anNadwi, Surabaya: al-idayah, 1998

al-Jailani, Abdul Qadir. Babul Tashawwuffii al-Ghunyah Lithalibi Thariq al-Haqq, terj. Aguk Irawan, Jakarta: Zaman, 2012

Alon, Ilai. "Al-Ghazālī on Causality", Journal of the American Oriental Society, 100 (4) (1980), pp. 397-405. Lebih lanjut lihat di link https://www.jstor.org/stable/602085

al-Taftazani, Abu al- Wafa' al-Ghanimi. Sufi Dari Zaman ke Zaman, Bandung: Pustaka, 1997 
Anjum, Ovamir. "Cultural Memory of the Pious Ancestors ("Salaf") in al-Ghazālī̄, Brill: Cultural Memory and Islam, 58 (2/3) (2011), https://www.jstor.org/stable/23045880.

Anwar, Rosihon dan Solihin, Mukhtar. Ilmu Tasawuf, Bandung: Pustaka Setia, 2000

Anwar, Saiful. Filsafat Ilmu al-Ghazali, Bandung: CV Pustaka Setia, 2007

Bahreisj, Hussein. Ajaran-ajaran Akhlak Imam Ghazali, Surabaya: Al-ikhlas, t.th.

Bakry, Hasbullah. Disekitar Filsafat Skolastik Islam, Jakarta: Tintamas, 1961

Basil, Victor Said. Manhaj al-Bahtsi'an al-Ma'rifah 'inda al-Ghazali, terj. Ahmadie Thaha, Jakarta: Pustaka Panjimas, 1990

Bowering, Gerhard. The Heritagr of Sufism: Clasical Persian Sufism from its Origin to Rumi, terj. Gafna Raizha Wahyuni, Yogyakarta: Pustaka Sufi, 2003

Chairani, Ikfina. "Dampak Pandemi Covid-19 dalam Perspektif gender di Indonesia", Jurnal Kependudukan Indonesia; Edisi Khusus Demografi dan Covid-19, (2020)

Dabasyi, Hamid. The Heritagr of Sufism: Clasical Persian Sufism from its Origin to Rumi, terj. Gafna Raizha Wahyuni, Yogyakarta: Pustaka Sufi, 2003

Dahlan, A. Zaini. "Konsep Makrifat Menurut al-Ghazali dan Ibnu 'Arabi; Solusi Antisipatif Radikalisme Keagamaan Berbasis Epistemologi”, Kawistara, 3 (1) (2013)

Dasoeki, Thawil Akhyar. Sebuah Kompilasi Filsafat Islam, Semarang: Dias Utama Semarang, 1993

E. Mulyasa, Manajemen Pendidikan Karakter, Bandung: Rosda, 2012

Emzir, Metodologi Penelitian Kualitatif Analisis Data, Jakarta: PT. RajaGrafindo Persada, 2012

Fazlur Rahman, Islam, Bandung: Penerbit Pustaka, 2000

Ghofur, Abdul. "Tasawuf Ghazali: Landasan Psikologi Pendidikan Islam", Jurnal Islam Nusantara 2 (1) (2018)

Handayani, Rina Tri dkk,"Pandemi Covid-19, Respom Imun Tubuh dan Herd Imunity", Jurnal Ilmiah Permas; Jurnal Ilmiah STIKES Kendal, 10 (3) (2020)

Hauglid, Brian M. "Al-Ghazali, a Muslim Seeker of Truth", Brigham Young University: A Special Issue on Islam, 40 (4) (2001), pp. 89-96. https://www.jstor.org/stable/43044282

Iqbal, Abu Muhammad. Konsep Pemikiran al-Ghazali tentang Pendidikan, Madiun: Jaya Star Nine, 2013 
J. Janssens,"Filosofische Elementen In De Mystieke Leer Van Al-Ghazali (Ihyâ, 31-36)", Peeters Publishers: Tijdschrift voor Filosofie, 50ste Jaarg., (2) (1988) https://www.jstor.org/stable/40885623.

Jahja, Muhammad Zurkani. Teologi Ghazali; Pendekatan Metodologi, Yokyakarta: Pustaka Pelajar, 1996

Jalil, Muhammad Hilmi. dkk, "Konsep Hati Menurut al-Ghazali”, Jurnal Reflektika 11 (11) (2016)

Kartanegara, Mulyadhi. Menyelami Lubuk Tasawuf, Jakarta: Erlangga, 2006

Lagerlund, Henrik. "Al-Ghazālī on the Form and Matter of the Syllogisms", Brill: Vivarium, Special Issue: Aristotelian Logic East and West, 500- 1500: "On Interpretation" and "Prior Analytics" in Two Traditions, 48 (1/2) (2010), https://www.jstor.org/stable/41963861.

Levering, Matthew. "Providence and Predestination in Al-Ghazali", Wiley: New Blackfriars, 92, (1037) (2011) https://www.jstor.org/stable/43251500

Madjid, Nurcholis. Kaki Langit Peradaban Islam, Jakarta: Paramadina, 1997

Madjid, Nurcholish. Islam Kemordenan dan Keindonesiaan, Jakarta: Mizan, 19881

Madjid, Nurcholish. Khazanah Intelektual Islam, Jakarta: Bulan Bintang, 1985

Mahmud, Abdul Qadir. al-Falsafah al-Sufiyyah al-Islam, Kairo: Dar al-Fikr, 1993

Mansur, M. Laily. Ajaran dan Teladan Para Sufi, Jakarta: PT. Raja Grafrindo, cet. 2, 1999

Moad, Edward Omar. "Al-Ghazali on Power, Causation, and 'Acquisition"', University of Hawai'i Press Philosophy East and West, 57 (1) (2007) https://www.jstor.org/stable/4488073

Nasr, Seyyed Hossein. Living Sufism, terj. Abdul Hadi, Jakarta: Pustaka Firdaus, cet. 51980

Nasution, Harun. Islam Ditinjau Dari Berbagai Aspek Jilid I, Jakarta: UI Press, 1985

Nst, Ahmad Bangun. (ed), Akhlak Tasawuf: Pengenalan, Pemahaman, dan Aplikasinya, Jakarta: PT RajaGrafindo Persada, tahun 2013

Nst, Kasron. "Konsep Keutamaan Akhlak Versi Ghazali", HIJRI: Jurnal Manajemen Pendidikan dan Keislaman, 6 (1) (2017)

Nurbakhsh, Javad dan Nasr, Seyyed Hossein. The Heritagr of Sufism: Clasical Persian Sufism from its Origin To Rumi, terj. Gafna Raizha Wahyuni, Yogyakarta: Pustaka Sufi, 2003

Nurbakhsh, Javad. In The Paradise of the Sufis, terj. Zaimul Am, Jakarta: Zaman, 2016

Tribakti: Jurnal Pemikiran Keislaman

Volume 32, Nomor 1, Januari 2021 
Pinasti, Faura Dea Ayu. “Analisis Dampak Pandemi Corona Virus Terhadap Tingkat Kesadaran Masyarakat dalam Penerapan Protokol Kesehatan", Wellness and healthy Magazine, 2 (1) (2020)

Rayan, Sobhi. "Al-Ghazali's Method of Doubt", Middle East Studies Association of North America (MESA): Middle East Studies Association Bulletin, 38 (2) (2004), pp. 162-173 lihat lebih lanjut di link https://www.jstor.org/stable/23062806

Senali, Moh. Saifullah al-Aziz. Risalah Memahami Ilmu Tasawuf, Surabaya: Terbit Terang, 1998

Smith, Margaret. "The Forerunner of al-Ghazālī", Cambridge University Press: The Journal of the Royal Asiatic Society of Great Britain and Ireland, (1) (1936), https://www.jstor.org/stable/25182038

Sofyan, Ayi. Kapita Selekta Filsafat, Bandung: CV Pustaka Setia, 2010

Sugiyono, Metodologi Penelitian Pendidikan PendekatanKuantitatif, Kualitatif dan $R$ \& $D$, (Bandung: Alfabeta, 2007

Taufik dan Ayuningtyas, Eka Avianti. "Dampak Pandemi Covid-19 terhadap Bisnis dan Eksistensi Platform Online", Jurnal Pengembangan Wiraswasta, 22 (1) (2020)

Yuliana, "Corona Virus Diseases (Covid-19); Sebuah Tinjauan Literatur", Wellness and healthy Magazine, 2 (1) (2020) 